\section{EFFECT OF TEMPERATURE ON RHEOLOGY BEHAVIOUR of Banana Peel Pectin extracted using Hot COMPRESSED WATER}

\author{
Noor Azwani Mohd Rasideka, Mariam Firdhaus Mad Nordina*, \\ Yus Aniza Yusofb, Hideaki Tokuyamac, Yuichiro Nagatsuc
}

aSHIZEN Conversion \& Separation Technology, Malaysia-Japan International Institute of Technology, Universiti Teknologi Malaysia, Jalan Semarak, 54100 Kuala Lumpur, Malaysia

bDepartment of Process Food Engineering, Faculty of Engineering, Universiti Putra Malaysia, 43400 UPM Serdang, Malaysia

cDepartment of Chemical Engineering, Tokyo University of Agriculture and Technology, 2-24-16 Nakacho, Koganei, Tokyo 184-8588, Japan
Article history

Received

14 August 2017

Received in revised form

9 November 2017

Accepted

15 January 2018

Published online

1 April 2018

*Corresponding author mariamfirdhaus@utm.my

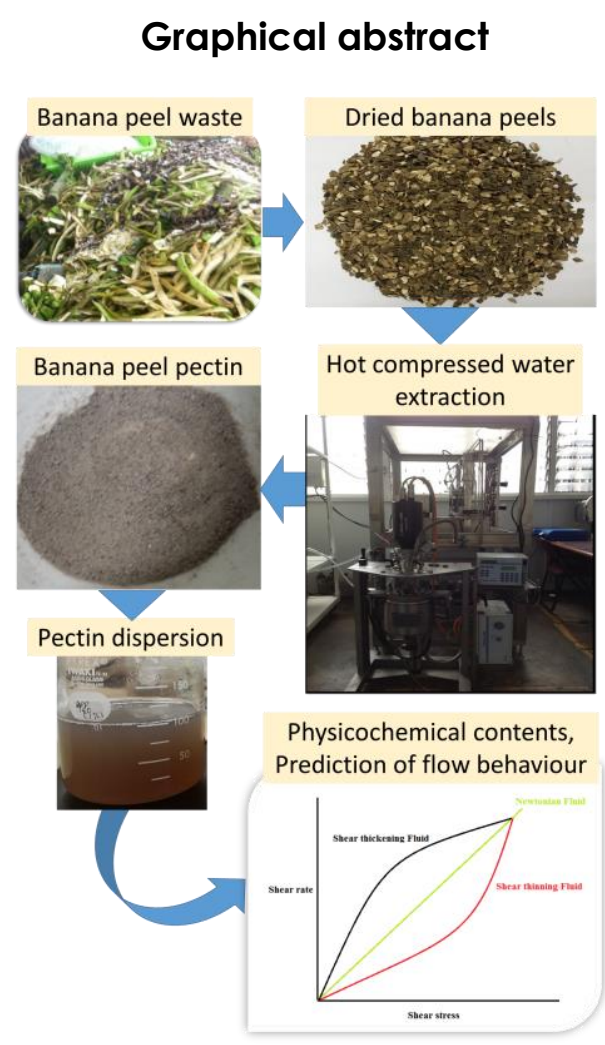

\begin{abstract}
Banana peel pectin is extracted from banana peel waste using a hot compressed water extraction ( $140-160^{\circ} \mathrm{C}, 5$ minutes, $1.18 \mathrm{~mm}$ particle size) Physicochemical contents of banana peel pectin were found to be in a similar range with commercial pectin, and is comprised of moisture (7.44$8.47 \%)$, ash (3.45-4.98\%), protein (1.08-1.92\%), fat (0.04-3.42), carbohydrate (83-86\%), total sugar (1.77-3.41\%), energy (353-369 $\mathrm{kcal} / 100 \mathrm{~g})$ and specific heat $\left(1.42-1.62 \mathrm{~kJ} / \mathrm{kg}^{\circ} \mathrm{C}\right)$. These contents possibly related to their flow deformation of rheological behaviour. Regression analysis displayed good agreements in all models applied, apart from the Casson Model. Flow behaviour indices, $n<1$ and decreasing of apparent viscosity within increasing of shear rate indicates that banana peel pectin has excellent shear thinning behaviour with a presence of yield stress.
\end{abstract}

Keywords: Banana peel, pectin, hot compressed water, rheology model, shear thinning

\begin{abstract}
Abstrak
Pektin kulit pisang telah diekstrak dari sisa kulit pisang menggunakan pengestrakan air panas termampat $\left(140-160^{\circ} \mathrm{C}, 5\right.$ minit, saiz zarah $1.18 \mathrm{~mm}$ ). Kandungan fizikokimia pektin kulit pisang didapati berada dalam lingkungan yang sama dengan pektin komersil, yang terdiri daripada kelembapan (7.44$8.47 \%$ ), abu (3.45-4.98\%), protein (1.08-1.92\%), lemak (0.04-3.42), karbohidrat (83-86\%), jumlah gula (1.77-3.41\%), tenaga (353-369 kcal/100g) dan haba spesifik $\left(1.42-1.62 \mathrm{~kJ} / \mathrm{kg}^{\circ} \mathrm{C}\right)$. Kandungan ini mungkin berkaitan dengan perilaku reologi ubah bentuk aliran. Analisa regresi menunjukkan penyesuaian yang baik untuk semua model yang digunakan, tetapi kurang ketepatan untuk Model Casson. Indeks tingkah aliran, $n<1$ dan penurunan kelikatan ketara dalam peningkatan kadar ricih. Oleh itu, pektin kulit pisang menunjukkan tingkah laku penipisan-ricih terbaik dengan kehadiran tegasan alah.

Kata kunci: Kulit pisang, pektin, air panas termampat, model reologi, penipisan-ricih
\end{abstract}

(C) 2018 Penerbit UTM Press. All rights reserved 


\subsection{INTRODUCTION}

Musa Paradisiaca cv. 'Tanduk' variety is one of popular local crop and their pulps are used primarily in chips manufacturing. However, local chips production generates substantial quantities of peel waste. The peels of the banana fruits is about $40 \%$ of the wet weight [1]. These peels are usually left to decompose after peeling process and some part being for animal feedstock. As increased the production of food products from banana fruits has led to accumulation of banana peels and consequently contributed into the disposal problem.

The utilization of banana peels is that it could be used as a source of pectin. Pectins are complex polysaccharides comprised mainly of galacturonic acid units being linked by $a-(1 \rightarrow 4)$ linkages that naturally found in higher plants. Commonly, the gelling properties of pectin are widely used in food, pharmaceutical and cosmeceutical industries. Commercially, pectin is generously extracted from citrus peel, apple pomace and to a smaller extent of sugar beet pulp by treating the raw material with hot dilute mineral acid with elevated temperature $[2,3,4]$. Concerning of acidic effluents from the commercial extraction that eventually contributes to our environmental problem. Thus, encourage to explore an alternative extraction methods including ultrasonic [5] microwave [6] and hot compressed water [7] and more attractive.

Generally, in food process the modelling, optimization and automation is challenging based on the complexity of the raw materials and product involved, which influence the thermophysical properties [8]. Moreover, certain food products demonstrate extensive changes with temperature and water content during processing [8]. Hence, the objectives of this study is to extract a pectin from banana peels using a hot compressed water extraction then determine the physicochemical composition of extracted pectin and to correlate their composition with prediction models on rheological behaviour as affected by different extraction temperature.

\subsection{METHODOLOGY}

\subsection{Materials and Reagents}

Banana peels from 'Tanduk' variety were freshly collected from local chips industry right after peeling process. The peels were soaked for 5 minutes and cleaned using fruit detergent to remove any impurities. Then, oven-dried at $50^{\circ} \mathrm{C}$ for 48 hours before grounded into $1.18 \mathrm{~mm}$ of particle size. The powdered sample was stored at room temperature for further extraction process.

Commercial apple pectin as comparable product purchased from Sigma chemical Co. (St. Louis, MO, USA). All other chemicals used in this study were analytical grade.

\subsection{Extraction of Pectin by Hot Compressed Water}

Pectin extraction from dried banana peels was carried out using the hot compressed water extraction according to the method of Wang et al. [7] with some modifications. The thermocouple and pressure gauge were used to assay the temperature and pressure inside the reactor. About $10 \mathrm{~g}$ of powdered banana peels were added into $500 \mathrm{ml}$ of water as main solvent. The extraction temperature was set at $140^{\circ} \mathrm{C}, 150^{\circ} \mathrm{C}$ and $160^{\circ} \mathrm{C}$ and extraction time was set for $5 \mathrm{~min}$. All the experiments were performed in triplicate, with the average values reported.

\subsection{Pectin Yield}

The flow preparation of banana peel pectin (BPP) was simplified as shown in Figure 1.

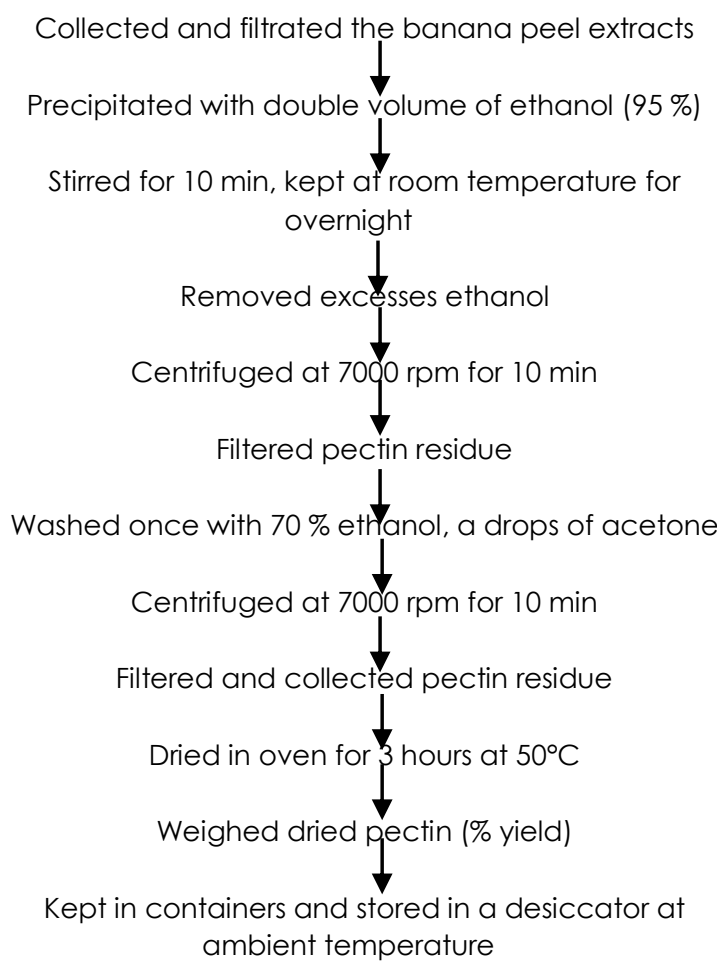

Figure 1 Flow of banana peel pectin preparation

After extraction process, the peel extracts were retrieved by filtration and the filtrate was collected for ethanol precipitation. Precipitation of peel extracts were established using double volume of 95\% ethanol and left for 24 hour at room temperature. Then, the precipitates were centrifuged at 7,000 rpm/5 min. The coagulated pectin was filtered using an ashless filter paper to collect the wetted pectin. Wetted pectin was rinsed two times using $70 \%$ ethanol and drop wisely of acetone to remove unwanted colour. Finally, the wetted pectin was dried in oven at $50^{\circ} \mathrm{C}$ until less than $\pm 10 \%$ of moisture content.

Therefore, the percentage of pectin yield was calculated as gram of dried pectin obtained per gram of dried peel of raw material used as follows equation: 
Pectin Yield $(\mathrm{w}+\%)=\frac{\text { Dried pectin }(\mathrm{g})}{\text { Dried peel raw }(\mathrm{g})} \times 100$

\subsection{Physicochemical Composition of Pectin}

\subsubsection{Moisture Content}

Moisture content of pectin products were analyzed using Malaysia Standard (MS 1191:1991) [9]. The moisture content (\%) was calculated as follows:

\section{Initial sample weight - dried sample weight $\times 100$ Initial sample weight}

\subsubsection{Ash Content}

The ash content was determined using standard (AOAC 32.1.05) [10], by weighing about of $3 \mathrm{~g}$ pectin sample into a tared crucible. Ignite for overnight at temperature of $550^{\circ} \mathrm{C}$. Allow crucibles to cool before weighed the tared crucible with left matter. The ash content is calculated as follows:

$$
\text { wt after ashing-tare wt of crucible } \quad \times 100
$$
original sample wt $\times$ dry matter coefficient

\subsubsection{Crude Fat Content}

About $2 \mathrm{~g}$ of pectin in extraction thimble $\left(W_{l}\right)$ and extraction cups $\left(W_{2}\right)$ were weighed. The extraction set was prepared by loaded the thimbles. The solvent recovery flask was inserted and $40 \mathrm{ml}$ diethyl ether solvent was added. Programme and extraction process was set at submerged boiling position for $40 \mathrm{~min}$. The extraction cups were removed after extraction process completed and the cups were dried. The extracted fat $\left(W_{3}\right)$ left in extraction cups were calculated as percentage of crude fat using follows equation:

$\%$ Crude fat $=\frac{W_{3}-W_{2}}{W_{1}} \times 100$

where, $W_{1}$ is sample in extraction thimble, $W_{2}$ is weight extraction cups and $W_{3}$ is weighed extraction cups with extracted fat.

\subsubsection{Crude Protein Content}

The protein analysis were involved of few steps which are digestion, distillation and titration. About $3 \mathrm{~g}$ of pectin sample was digested in $98 \%$ of sulfuric acid. It was to help the conversion of the amine nitrogen to ammonium ions. Then, the ammonium ions are converted into ammonia gas, heated and distilled. During distillation process, the ammonia gas is led into a trapping solution where it was dissolved and became an ammonium ion once again. Finally the amount of the ammonia that has been trapped is determined by titration. Thus, the percentage of crude protein was determined using follows equation;

\% Nitrogen $=\frac{14.01 \times \mathrm{N} \mathrm{H}_{2} \mathrm{SO}_{4} \times \text { Volume } \mathrm{H}_{2} \mathrm{SO}_{4}}{\mathrm{Sample}}$ Sample weight $\times 10$
$\%$ Crude Protein $=\%$ Nitrogen $\times 6.25$

\subsubsection{Carbohydrates}

Carbohydrate is one of the most important components in food. Hence, the carbohydrate content of pectin was determined according to the standard method (Malaysia Food Regulations 1985) by calculating the percent remaining after all the other components have been measured as shown in the following equation [9];

Total carbohydrates (g/100g); 100 - Total [Moisture, Ash, Protein, Fat]

\subsubsection{Total Sugar}

Total sugar was determined using standard method (AOAC 44.1.15) whereby the total sugars were calculated according to the following equation [10]:

\section{\% Total sugar; mg of sugar/100ml of sol $x$ dilution factor $\times 100$ $1000 \times$ weight of sample}

\subsubsection{Total Energy}

Determination of total energy was established according to standard method [9]. A calorie (kcal) is a unit that has used to measure an energy. A kcal represented the amount of energy needed to raise the temperature of 1 kilogram of water 1 degree Celsius. Calculation of the energy value are based on Atwater factors, by multiply grams of each composition in the food by calories per gram which is $4.0 \mathrm{kcal} / \mathrm{g}$ for protein, $4.0 \mathrm{kcal} / \mathrm{g}$ for carbohydrates and $9.0 \mathrm{kcal} / \mathrm{g}$ for fat.

\subsubsection{Specific Heat Capacity}

Specific heat capacity was determined from proximate contents using equation below proposed by Heldman and Singh (1981) [11]:

$$
\begin{aligned}
C_{p}= & 1.424 m_{c}+1.549 m_{p}+1.675 m_{f}+0.837 m_{a} \\
& +4.187 m_{m}
\end{aligned}
$$

where $m_{c}$ is mass fraction of carbohydrates, $m_{p}$ is mass fraction of fat, $m_{f}$ is mass fraction of fat, $m_{a}$ is mass fraction of ash and $m \mathrm{~m}$ is mass fraction of moisture.

\subsection{Rheological Behaviour}

The rheological behaviour of BPP (BPP) were analyzed using a rheometer (AR-G2, TA instruments, USA) with a $25 \mathrm{~mm}$ parallel plate. The pectin dispersion was prepared by weighing the sample and dissolving in hot deionized water (2\% w/w), rapidly stirred for $3 \mathrm{~min}$. The pectin dispersion was rested for overnight prior to the measurement. The steady shear measurement was conducted at $25^{\circ} \mathrm{C}$, which the shear rate ranged from 0.01 to 100 $\mathrm{s}^{-1}$. All experiments were repeated at least twice. The reported results were showed in averages of 
these multiple trials to exhibit an excellent reproducibility.

\subsection{RESULTS AND DISCUSSION}

\subsection{Effect of Temperature on Pectin Yield}

Table 1 shows the effect of temperature on BPPs yield which is extracted at temperatures of $140^{\circ} \mathrm{C}$, $150^{\circ} \mathrm{C}$ and $160^{\circ} \mathrm{C}$. As the extraction temperature increased, there was found a decrease of pectin yield from $4.84 \pm 0.03$ to $4.38 \pm 0.14 \%$. This finding meets the agreement as revealed by Wang et al (2014), that the temperature significantly affected the pectin yield [7] even though the yield percentage of BPPs were not much different, albeit in a similar range of 4 .

Table 1 Percentage yields of banana peel pectin

\begin{tabular}{cccc}
\hline \multirow{2}{*}{$\begin{array}{c}\text { Extraction } \\
\text { Runs }\end{array}$} & \multicolumn{3}{c}{$\begin{array}{c}\text { Banana Peel Pectin } \\
\text { (\% Yield) }\end{array}$} \\
\cline { 2 - 4 } & $140^{\circ} \mathrm{C}$ & $150^{\circ} \mathrm{C}$ & $160^{\circ} \mathrm{C}$ \\
\hline Run 1 & 4.83 & 4.73 & 4.44 \\
Run 2 & 4.75 & 4.80 & 4.27 \\
Run 3 & 4.87 & 4.78 & 4.50 \\
Run 4 & 4.81 & 4.82 & 4.23 \\
Run 5 & 4.85 & 4.72 & 4.42 \\
Average & 4.84 & 4.77 & 4.38 \\
Standard & & & \\
Deviation, SD & 0.03 & 0.05 & 0.14 \\
\hline
\end{tabular}

However, pectin yield presence in this study was much lower than found in Emaga et al. [1] which reported around 2.4 to $21.7 \%$ in which they extracted the pectin from banana peels under acidic conditions. In addition, a possible explanation for such a difference is that because of the sample was treated in acidic conditions, variety and environmental growth conditions of the banana peels were used. Moreover, the pectin yield also depends on the process conditions which contribute some impurities and could degrade the pectin yield [1].

\subsection{Physicochemical Composition}

The results of the physicochemical analysis of BPPs and the commercial apple pectin are shown in Table 2. Each composition of moisture, ash, protein, fat, carbohydrates, sugar and energy were reached similarly within the range of commercial apple pectin. The comparison trends are shown in Figure 2 (a-b). All compositions showed an insignificant result with the extraction temperature studied as the $p$-value is more than 0.05 .

\subsection{Specific Heat Capacity}

The specific heat capacity, $C_{p}$, for all pectin samples ranged from 1.42 to $1.62 \mathrm{~kJ} / \mathrm{kg}^{\circ} \mathrm{C}$. Each value of $C_{p}$ given is the average of three replicates. The specific heat capacity of commercial apple pectin is found to be in the same range. Main components consisted of carbohydrate, protein, fat, ash, and moisture and have contributed to the high $\mathrm{C}_{p}$ value.

Table 2 Physicochemical composition of banana peel pectin extracted using hot compressed water

\begin{tabular}{|c|c|c|c|c|}
\hline $\begin{array}{l}\text { Proximate } \\
\text { composition } \\
(\mathrm{g} / 100 \mathrm{~g})\end{array}$ & $\begin{array}{l}\text { BPP } \\
140\end{array}$ & $\begin{array}{l}\text { BPP } \\
150\end{array}$ & $\begin{array}{l}\text { BPP } \\
160\end{array}$ & $\begin{array}{l}\text { Com. } \\
\text { Apple } \\
\text { Pectin }\end{array}$ \\
\hline Moisture & $\begin{array}{c}7.44 \pm \\
0.14 \\
\end{array}$ & $\begin{array}{c}7.44 \pm \\
0.14 \\
\end{array}$ & $\begin{array}{c}8.47 \pm \\
0.06\end{array}$ & $\begin{array}{c}8.95 \pm \\
0.03\end{array}$ \\
\hline Ash & $\begin{array}{c}4.98 \pm \\
0.20\end{array}$ & $\begin{array}{c}4.40 \pm \\
0.04\end{array}$ & $\begin{array}{c}3.45 \pm \\
0.08\end{array}$ & $\begin{array}{c}3.58 \pm \\
0.28\end{array}$ \\
\hline Protein & $\begin{array}{l}1.24 \pm \\
0.01\end{array}$ & $\begin{array}{l}1.08 \pm \\
0.10\end{array}$ & $\begin{array}{l}1.92 \pm \\
0.04\end{array}$ & $\begin{array}{l}1.42 \pm \\
0.10\end{array}$ \\
\hline Fat & $\begin{array}{c}3.42 \pm \\
0.14\end{array}$ & $\begin{array}{l}3.22 \pm \\
0.15\end{array}$ & $\begin{array}{c}0.04 \pm \\
0.00\end{array}$ & $\begin{array}{c}0.01 \pm \\
0.00\end{array}$ \\
\hline Carbohydrates & $\begin{array}{c}82.65 \pm \\
0.80 \\
\end{array}$ & $\begin{array}{c}83.86 \pm \\
0.16\end{array}$ & $\begin{array}{c}86.12 \pm \\
0.54\end{array}$ & $\begin{array}{c}86.04 \pm \\
0.08\end{array}$ \\
\hline $\begin{array}{l}\text { Chemical } \\
\text { composition }\end{array}$ & BPP140 & BPP 150 & BPP 160 & $\begin{array}{l}\text { Com. } \\
\text { Apple } \\
\text { Pectin }\end{array}$ \\
\hline $\begin{array}{c}\text { Total Sugar } \\
\text { (g/100g) }\end{array}$ & $\begin{array}{c}3.41 \pm \\
0.02 \\
\end{array}$ & $\begin{array}{l}1.77 \pm \\
0.08 \\
\end{array}$ & $\begin{array}{c}2.04 \pm \\
0.05 \\
\end{array}$ & $\begin{array}{l}2.71 \pm \\
0.06 \\
\end{array}$ \\
\hline $\begin{array}{c}\text { Energy } \\
\text { (kcal/100g) }\end{array}$ & $\begin{array}{c}366 \pm \\
0.49\end{array}$ & $\begin{array}{c}369 \pm \\
0.16\end{array}$ & $\begin{array}{c}353 \pm \\
0.32\end{array}$ & $\begin{array}{l}350 \pm \\
0.17\end{array}$ \\
\hline $\begin{array}{c}\text { Physical } \\
\text { composition }\end{array}$ & BPP140 & BPP 150 & BPP160 & $\begin{array}{l}\text { Com. } \\
\text { Apple } \\
\text { Pectin }\end{array}$ \\
\hline $\begin{array}{c}\text { Specific heat } \\
\text { capacity, Cp } \\
\left(\mathrm{kJ} / \mathrm{kg}^{\circ} \mathrm{C}\right)\end{array}$ & 1.620 & 1.424 & 1.424 & 1.424 \\
\hline
\end{tabular}

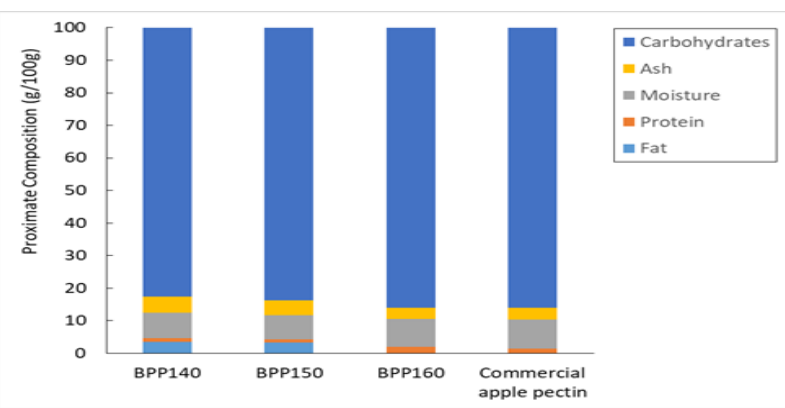

(a) Proximate composition

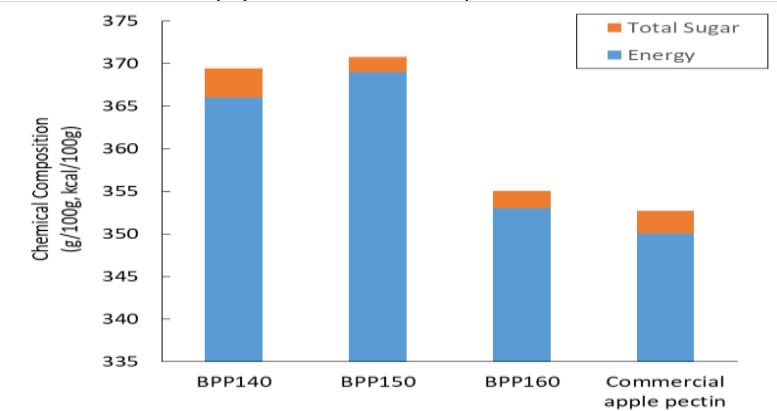

(b) Total sugar and energy

Figure 2 Composition of banana peel pectin extracted at temperature of $140^{\circ} \mathrm{C}, 150^{\circ} \mathrm{C}$ and $160^{\circ} \mathrm{C}$ and commercial apple pectin

\subsection{Rheological Behaviour}

Rheological data for BPPs and the commercial apple pectin were fitted into several rheological 
models; Power Law, Bingham, Casson and Hershey Bulkey Models. The shear stress against shear rate results were placed on a linear scale graph to determine whether there is an apparent yield stress either shear thinning or dilatant behaviour [12]. If the relationship showed linear behaviour then Newtonian models should be tested and appropriate regression analysis is required. Thus, in Table 3 , it shows the parameters of selected models for BPPs and commercial apple pectin at $25^{\circ} \mathrm{C}$.

\subsubsection{Newtonian Model}

Numerous ranges of dispersion of food products or other polysaccharides show a simple Newtonian behaviour. The product shows that Newtonian behaviour has a linear relationship between shear stress, $\sigma(\mathrm{Pa})$, and shear rate, $\dot{Y}\left(\mathrm{~s}^{-1}\right)$ :

$$
\sigma=\eta \dot{Y}
$$

where the $\eta$ is viscosity in unit Pa.s. The plot of BPPs shown in Figure 3 (a-d), which passed through at origin $(0,0)$. It reveals that the flow behaviour of all pectin products appears to be Newtonian.
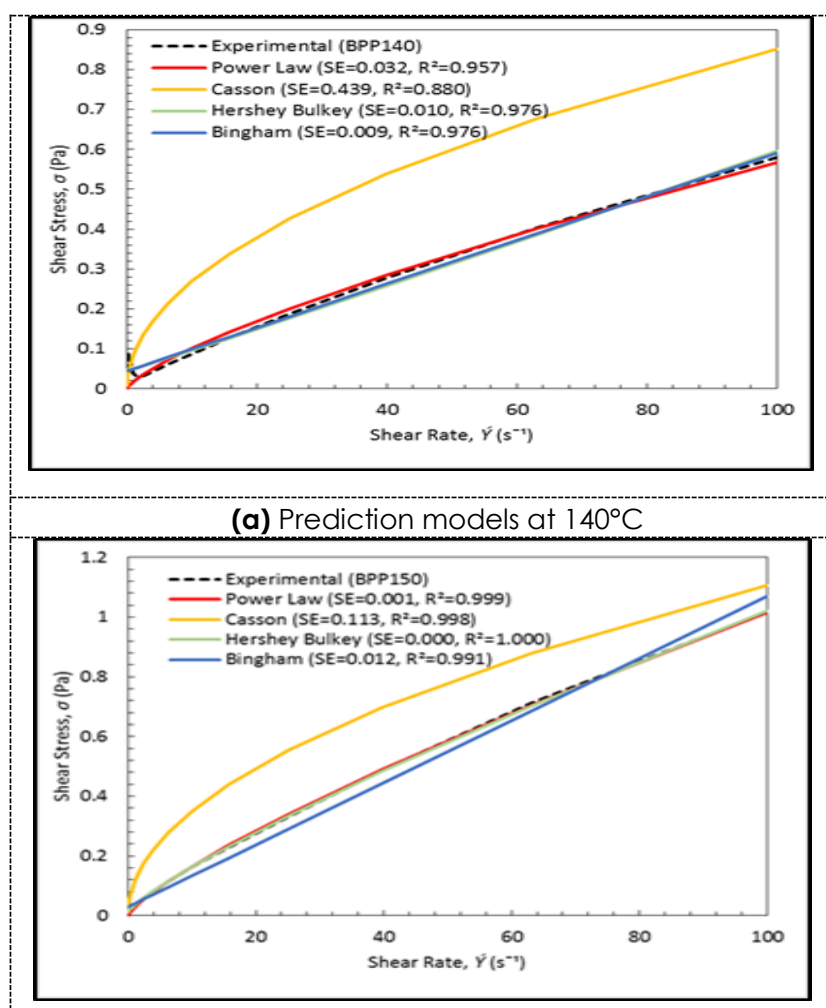

(b) Prediction models at $150^{\circ} \mathrm{C}$

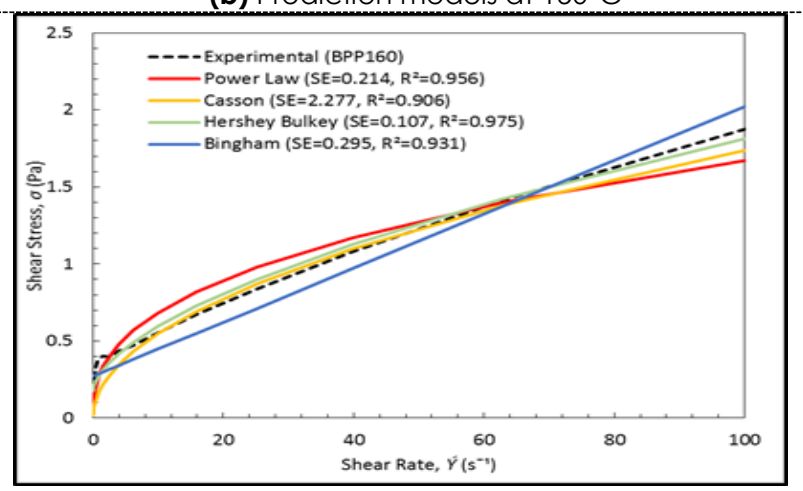

(c) Prediction models at $160^{\circ} \mathrm{C}$

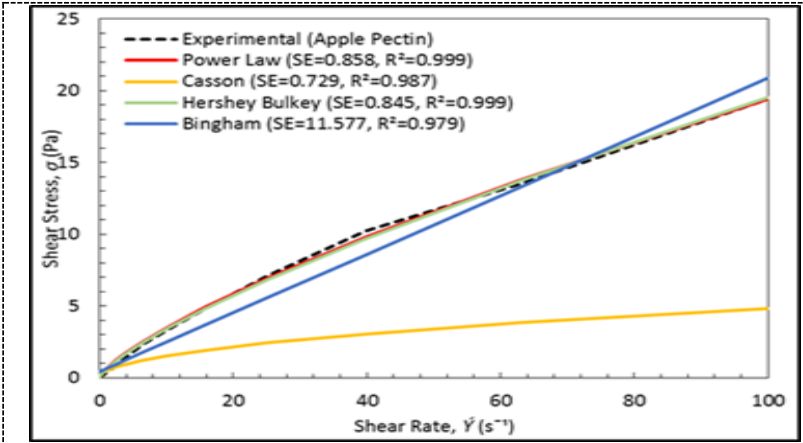

(d) Prediction models for commercial apple pectin

Figure 3 (a-d) Effect of extraction temperature on rheological behaviour of banana peel pectin and commercial apple pectin fitted using Bingham, Power Law, Hershey Bulkey and Casson Models

Table 3 Parameters of selected models for banana peel pectin and commercial apple pectin at $25^{\circ} \mathrm{C}$

\begin{tabular}{|c|c|c|c|c|}
\hline \multicolumn{5}{|c|}{ Power Law } \\
\hline & BPP 140 & BPP 150 & BPP 160 & $\begin{array}{l}\text { Com. } \\
\text { Apple } \\
\text { Pectin }\end{array}$ \\
\hline$n$ & 0.749 & 0.791 & 0.389 & 0.744 \\
\hline K & 0.018 & 0.027 & 0.279 & 0.630 \\
\hline$R^{2}$ & 0.957 & 0.999 & 0.956 & 0.999 \\
\hline SE & 0.032 & 0.001 & 0.214 & 0.858 \\
\hline \multicolumn{5}{|c|}{ Bingham } \\
\hline & BPP 140 & BPP 150 & BPP 160 & $\begin{array}{l}\text { Com. } \\
\text { Apple } \\
\text { Pectin }\end{array}$ \\
\hline$K^{\prime}$ & 0.005 & 0.010 & 0.017 & 0.204 \\
\hline$\sigma_{\circ}$ & 0.044 & 0.029 & 0.273 & 0.451 \\
\hline$R^{2}$ & 0.976 & 0.991 & 0.931 & 0.979 \\
\hline SE & 0.009 & 0.012 & 0.295 & 11.577 \\
\hline \multicolumn{5}{|c|}{ Casson } \\
\hline & BPP140 & BPP 150 & BPP 160 & $\begin{array}{l}\text { Com. } \\
\text { Apple } \\
\text { Pectin }\end{array}$ \\
\hline$K_{c}$ & 0.022 & 0.030 & 0.071 & 0.239 \\
\hline$K_{o c}$ & 0.063 & 0.080 & 0.103 & 0.248 \\
\hline$\sigma_{o c}$ & 0.004 & 0.006 & 0.011 & 0.061 \\
\hline$\eta_{c a}$ & 0.000 & 0.001 & 0.005 & 0.057 \\
\hline$R^{2}$ & 0.880 & 0.998 & 0.906 & 0.987 \\
\hline SE & 0.439 & 0.113 & 2.277 & 0.729 \\
\hline \multicolumn{5}{|c|}{ Hershey Bulkey } \\
\hline & BPP 140 & BPP 150 & BPP 160 & $\begin{array}{l}\text { Com. } \\
\text { Apple } \\
\text { Pectin }\end{array}$ \\
\hline$n_{H}$ & 1.040 & 0.821 & 0.585 & 0.761 \\
\hline$\sigma_{\circ}$ & 0.046 & 0.011 & 0.168 & 0.020 \\
\hline$K_{H}$ & 0.005 & 0.023 & 0.111 & 0.588 \\
\hline$R^{2}$ & 0.976 & 1.000 & 0.975 & 0.999 \\
\hline SE & 0.010 & 0.000 & 0.107 & 0.845 \\
\hline
\end{tabular}

\subsubsection{Power Law}

The Power Law Model commonly has been used in food processing inspection based on handling, heating or cooling of food. The Power Law indicates a virtuous description of fluid flow 
behaviour in the range of shear rate. Hence, it's easy to measure with most rheological instruments;

$$
\sigma=K Y^{n}
$$

where $\sigma(\mathrm{Pa})$ is shear stress, $K\left(\mathrm{~Pa} . \mathrm{s}^{\mathrm{n}}\right)$ is consistency index, $Y\left(\mathrm{~s}^{-1}\right)$ is the shear rate and $n$ which is flow behavior is dimensionless.

The fitted Power Law plots were showing approximation of viscosity parameters $(K)$ and flow behavior index $(n)$. It was indicated the degree of shear thinning, as the decrease of $n$ denoted a greater shear thinning behavior of the product. Practically, the flow behavior index, $n$ was found to not change with the temperature $[13,14,15]$.

Based on the findings, the BPP 150 and commercial apple pectin showed a good fit to the Power Law with $R^{2}$ at 0.999, while the flow index $n$ for BPP140, BPP150 and commercial apple pectin found in same range of 0.7. However, the BPP 160 was decreased which denoted as greater shear thinning behaviour.

Moreover, higher $K$ values were presented at higher viscosity. The $K$ value of BPP 160 is 0.3 which was the highest amongst the others. Meanwhile, the commercial apple pectin was found to be more viscous with a value of 0.6. Thus, the shear thinning effect for each BPP decreases within the extraction temperatures of 140,150 and $160^{\circ} \mathrm{C}$.

Meanwhile, the values of $R^{2}$ for BPP150 and commercial apple pectin were higher which indicated that the Power Law successfully predicted the viscosity properties. However, the $R^{2}$ of BPP 140 and BPP 160 were lower than 0.96 which presented a lower viscosity prediction.

\subsubsection{Bingham Model}

Generally, the foodstuff presenting the Newtonian linear relationship of $\sigma / \bar{Y}$, exhibits a yield stress, $\sigma_{\circ}$ and shows viscoplastic behaviour. The constant, $K^{\prime}$, is known as the plastic viscosity and their units is Pa.s. The Bingham equation model is as follows;

$$
\sigma=\sigma_{0}+K^{\prime} \dot{Y}
$$

Figure 3 shows fair agreement with equation [10]. The BPP150 is the most reasonably fitted of these data on Bingham Model with $R^{2}$ is 0.99 . A higher yield stress, $\sigma_{\circ}$ was remarkable for BPP 160 and the commercial apple pectin with 0.27 and 0.45 respectively. This showed that flow properties could be observed under the conditions of experimentation.

\subsubsection{Casson Model}

The Casson Model is widely used in a range of food products, for instance in fruit purees, gums and tomato sauces $[12,13,15,16]$. A straight line result was shown when square root of shear rate $\left(Y^{0.5}\right)$, is plotted against the square root of shear stress $\left(\sigma^{0.5}\right)$ with slope $K_{c}$ and intercept $K_{\text {occ }}$. Therefore, these model appearances are as stated below;

$$
\sigma^{0.5}=K_{o c}+K_{c}\left(Y^{0.5}\right)
$$

However, the Casson yield stress ( $\left.\sigma_{\circ c}\right)$ is calculated as the square of intercept, $\sigma_{o c}=\left(K_{o c}\right)^{2}$ and plastic viscosity $\eta_{c a}=\left(K_{c}\right)^{2}$. The prediction of Casson Model for all pectins comprised the least $R^{2}$ value ranging from 0.88 to 0.99 . The Casson yield value, $\sigma_{o c}$, is referred as the limitation value of the stress below which, material cannot be sheared. The Casson plastic viscosity, $\eta_{c a}$, represents the viscosity limitation of the material at an infinite rate of shear [16]

\subsubsection{Hershey Bulkey Model}

The Herschel-Bulkey Model explains the materials with a combination of the Power Law and Bingham. Thus, the model could be expressed mathematically as an equation;

$$
\sigma=K_{H}(\dot{Y})^{n H}+\sigma_{\circ}
$$

Hershey Bulkey parameters were presented in Table 3. The $n$ values for BPPs are decreasing as extraction temperature was increased, from 1.0 to 0.5 . These values indicated an excellent shear thinning behaviour for BPP160. The prediction data of BPP150 is best fitted with $R^{2}$ is 1 .

\subsubsection{Apparent Viscosity}

Figure 4 was illustrated the variation of apparent viscosity at different extraction temperatures, which is observed as the shear thinning behaviour in nature.

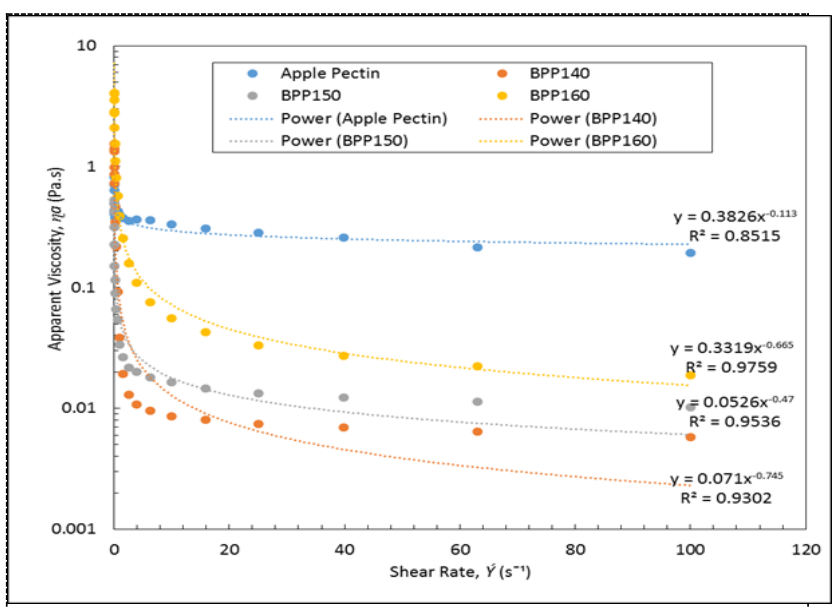

Figure 4 Changes in apparent viscosity as shear rate increases for banana peel pectin and commercial apple pectin

As suggested by Keshani et al. [13] the increase of shear rate decreased the apparent viscosity. Overall, the apparent viscosities of BPPs were denoted from 4.65 to 13.64 Pa.s, while the BPP160 contributed the highest compared to other BPPs. Contrarily, the commercial apple pectin was found to be a bit higher with a value of 13.8 Pa.s.

As findings, the apparent viscosity curve showed strong shear thinning behaviour. It is due to the chemical composition including water, fat and carbohydrates contents that have a lubricating 
effect between the particles and flow relatives unrestricted [13].

\subsection{CONCLUSION}

The physicochemical composition of banana peel pectin extracted using hot compressed water extraction was almost identical to the commercial apple pectin. Regression analysis showed a good agreement with the Power Law, Bingham and Hershey Bulkey, but less prediction for the Casson Model. The best prediction for all models could only be observed for BPP150. Overall, the banana peel pectin exhibited shear thinning behaviour under the conditions tested, as indicated by flow behaviour indices, $n<1$. The apparent viscosity curve also showed a strong shear thinning behaviour.

\section{Acknowledgement}

The authors would like to express their appreciation for the Research University Grant Scheme of Tier 1 with grant no. PY/2014/03649 provided by Universiti Teknologi Malaysia, Tokyo University of Agriculture Technology for facilities provided and Universiti Putra Malaysia for technical assistance.

\section{References}

[1] Emaga, T. H., Ronkart, S. N., Robert, C., Wathelet, B., and Paquot, M. 2008. Characterisation of Pectins from Banana Peels (Musa AAA) under Different Conditions Using an Experimental Design. Food Chemistry. 2(108): 463-471.

[2] Srivastava, P., and Malviya, R. 2011. Sources of Pectin, Extraction and Its Applications in Pharmaceutical
Industry-An Overview. Indian Journal of Natural Products and Resources. 1 (2): 10-18.

[3] Yapo, B. M., Robert, C., Etienne, I., Wathelet, B., and Paquot, M. 2007. Effect of Extraction Conditions on the Yield, Purity and Surface Properties of Sugar Beet Pulp Pectin Extracts. Food Chemistry. 100: 1356-1364.

[4] May, C. D. 1990. Industrial Pectins: Sources, Production and Applications. Carbohydrate Polymers. 12: 79-99.

[5] Zhang, L., Ye, X., Ding, T., Sun, X., Xu, Y., and Liu, D. 2013. Ultrasound Effects on the Degradation Kinetics, Structure and Rheological Properties of Apple Pectin. Ultrasonics Sonochemistry. 1 (20): 222-231.

[6] Fishman, M. L., and Cooke, P. H. 2009. The Structure of High-Methoxyl Sugar Acid Gels of Citrus Pectin as Determined by AFM. Carbohydrates Research. 14(344): 1792-1797.

[7] Wang, X., Chen, Q., and LU, X. 2014. Pectin Extracted from Apple Pomace and Citrus Peel by Subcritical Water. Food Hydrocolloids. 38:129-137.

[8] Telis-Romero, J., Telis, V. R. N., Gabas, A. L., and Yamashita, F. 1998. Thermophysical Properties Of Brazilian Orange Juice as Affected By Temperature and Water Content. Journal of Food Engineering. 1(38): 2740.

[9] Standard method (Malaysia Food Regulations 1985).

[10] AOAC. 15th edition. 1990 Official Method.

[11] Heldman, D. R., and Singh, R. P. 1981. Food Process Engineering. Westport, CT, USA: AVI.

[12] Holdsworth, S. D. 1993. Rheological Models Used for the Prediction of the Flow Properties of Food Products: A Literature Review. Transactions of the IChemE. 71: 139179

[13] Keshani, S., Luaman Chuah, A., and Russly, A. R. 2012 Effect of Temperature and Concentration on Rheological Properties Pomelo Juice Concentrates. International Food Research Journal. 2(19): 553-562.

[14] Nindo, C. I., Tang, J., Powers, J. R., and Takhar, P. S. 2007 Rheological Properties of Blueberry Purees for Processing Applications. Swiss Society of Food Science and Technology. 40: 292-299.

[15] Rao, M. A. 1999. Rheology of Fluid and Semisolid Foods (Principles and Applications).

[16] Chuah, T. G., Hairul Nisah, H., Thomas Choong, S. Y., Chin, N. L., and Nazimah Sheikh, A .L. 2007. Effects of Temperature on Viscosity of Dodol (Concoction). Journal of Food Engineering. 80: 423-430. 